\title{
The Development Strategy of Paksebali Village Into Smart Eco-Village Destination as a Tourism Icon
} in Klungkung District-Bali

\author{
$1^{\text {st }}$ I Wayan Pantiyasa \\ Hospitality Management Study Program \\ Sekolah Tinggi Pariwisata Bali \\ Internasional \\ Bali, Indonesia \\ pantiyasa@stpbi.ac.id
}

\author{
$2^{\text {nd }}$ Putu Devi Rosalina \\ Hospitality Management Study Program \\ Sekolah Tinggi Pariwisata Bali \\ Internasional \\ Bali, Indonesia \\ putudevi@stpbi.ac.id
}

\begin{abstract}
The purpose of this study is to know the tourism potential, how the management condition of tourism village of Paksebali, and how the alternative strategies in the development of tourism village of Paksebali. The data was collected through observation, interview, documentation, and focus group discussion, it was then analyzed by descriptive analysis and SWOT analysis. The results of this study indicates that the tourism potential consists of the enchanting tourists' attractions both natural, socio-cultural, and social community. The accessibility is good as it is near the famous destinations such as Besakih and Kertagosa. Amenities are available, for instance: restaurant, public toilets, jogging tracks. The organization structure of tourism village destination management has been formed but there is no part of marketing, yet some officials have several duties and responsibilities. The development of Paksebali Tourism Village is in the condition of growth oriented strategy. The alternative strategies that can be arranged in its development are maintaining product quality, improving of tourism infrastructure, improving management and improving human resources quality, improving information technology, conducting better cooperation with travel agency company, increasing the role of the community in monitoring and promoting through social media
\end{abstract}

Keywords-tourist attraction; accessibility; amenities; SWOT analysis; growth oriented strategy

\section{INTRODUCTION}

In the Strategic Plan of Klungkung Regency Tourism Office in 2013 - 2018 explained that the vision of Klungkung Regency development is "Realization of Community Based Tourism Based on Tri Hita Karana in Improving the Welfare of Society". Tri Hita Karana based community contains the understanding of tourism development which always prioritizes community participation in aligning God-related development, amongst human being, as well as between human and environment (Tri Hita Karana), the development of tourism that preserve the cultural life of Hindu Balinese society and of which tourism gets world recognition in increasing the tourists' visit. Meanwhile Improving Public Welfare implies that the active role of society in development will be harmony of interest in the development, thus it could realize the security and comfort so that the welfare of society can be achieved.
Klungkung regency is one of the districts in Bali that has a variety of uniqueness, both beautiful nature as well as the richness of the culture. In 2016, the Government of Klungkung-Bali Regency began working on the concept of City Tour with the aim of boosting tourist visits to the city of Semarapura. The government city has conducted physical development to create branding of Semarapura as a City Tour or city tour. If there is a city tour, it is certain that there are rural tours that will be interesting to develop. According to Infonawacita.com (2017), the government through the Ministry of Cooperatives and SMEs fully supports the development of villages in Klungkung-Bali as a potential tourist village. Klungkung Regent I Nyoman Suwirta revealed, Klungkung district government has issued a decree (SK) Paksebali Dawan Sub-district, Klungkung as one of the tourism village of Klungkung regency. In addition, the Klungkung district government also assisted in improving local village infrastructure. Klungkung District Government seeks to have shuttle bus to the village. This is for tourism development such city tour in several villages in Klungkung.

According to Bali Travel News (2017), Paksebali Village, Klungkung Sub-district becomes the only village ready to carry the name of the tourist village, although not a priority in Klungkung Regency. Beside designing some of its attractions such as Kali Unda, Paksebali Village also began to develop agro tourism by making tracking path in the hills surrounding the Village area. In the online magazine Bali Travel News (2017) Head of Paksebali Village revealed that Paksebali Village has the potential of tourist attraction in the form of crafts, namely tedung, pedape, upakara with its distinctive ornaments of Paksebali. In addition, Paksebali Village has a natural tourist attraction, such as Tukad Unda and hilly areas with a view that is very beautiful and natural. The potential of tourism strongly supports the development of tourism in Klungkung regency.

However there are still some obstacles in the development of tourism in Paksebali Village, such as: 1) There are still many potential attractions that have not been well managed attraction and lack of tourism promotion, 2) Lack of making breakthroughs and coordination with related institutions and also promotion through electronic media, 3) The number of 
foreign and domestic tourist visit to Paksebali Village is much smaller compared to the number of tourist visit to several tourist attractions in Klungkung Regency. It is also revealed by Pradnyana (2015), that in the development of Paksebali Village tourism Klungkung Regency is constrained by low funds, the lack of participation from the government and the community to promote tourism as well as in the delivery of information which is still in the form of printed media, such as giving brochures, pamphlets, posters, and books.

In order to develop tourism by utilizing mutually beneficial relationships among villages and cities, the concept of eco village can be a solution in the development of tourism in the future. According to GEN (2000) in Shodiq (2009), Eco village is a spatial and territorial concept that pays attention to the quality of the population and the ecological quality in holistic, since it involves all dimensions of living beings. Eco village is a regional development, community and the quality of the sustainable natural environment. Thus, it is expected that villagers will have improved welfare without damaging the environment.

In order to realize the development of Paksebali Tourism village on online media based, it needs to develop the tourism village which leads to the smart village. Smart village is a development of the meaning of smart city. Its development concept implements village-level information-based communication as a complex interaction among the various systems within (Nashuilia, 2015). Therefore, it eventually could benefit its citizens effectively and to improve the quality of life, reduce costs and sources of consumption.

Paksebali tourism village has been running for 2 years but still in unprofitable income, which the average monthly income only reached 27 million rupiahs, this has not been able to finance the operational. Therefore, based on this fact, it needs an effective and efficient village tourism development strategy for the Village tourism so that it can run as expected by the community that is improving the welfare of the village community of Paksebali. From the various paradigm, this research will be done with the title of development strategy of Paksebali tourism village to smart Eco village destination as a tourism icon in Klungkung regency Bali.

\section{A. RESEARCH AIMS}

The research aims are as the followings :

1. To know the potential tourist attraction in Paksebali Tourism Village

2. To analyze the operational management manage Paksebali Tourism Village?

3. To improve the strategy of Paksebali Tourism Village Development to smart Eco Village destination?

\section{B. LITERARY REVIEW}

\section{The Tourism Village Potential}

The tourism village is a form of integration between attractions, accommodation, and aminities presented in a community life that blends with the prevailing rules and traditions. A tourism village has a unique appeal, which is wrapped naturally and attractively so that rural attractiveness can drive tourist visits to the village (Ministry of Culture and Tourism, (2011: 1). According to Priasukmana \& Mulyadi (2001), a tourism village is a rural area that offers a whole atmosphere that reflects the authenticity of the countryside both from socio-economic life, social culture, customs, everyday life, possessing typical building architecture and spatial village, or unique and interesting economic activities and having the potential for the development of various components of tourism, such as attractions, accommodation, food, beverages, souvenirs and other tourist needs. This is also reinforced by the Law of the Republic of Indonesia No. 10 of 2009 on Tourism, which states that the potential of tourism is anything that has the uniqueness, beauty and value in the form of diversity of natural wealth, culture and man-made products that become the target or purpose of tourist visits. According to Cooper et al (1993) states that there are 4 (four) components that must be possesed by a tourist attraction, those are Attraction, Accessibilities, Amenities and Ancillary services. Yoeti (2002) argues that the success of a tourist area is very dependent on the 3A of Attraction, Accessibilities, and Amenities. Madiun (2008) mentions that an additional component that is at the core of the development of tourism is Community Involvement.

\section{Community Based Tourism Management}

Tourism management is a planning, organizing, mobilizing and controlling action undertaken to determine and achieve predetermined targets through the utilization of human resources and other resources in tourism. Tourism management should refer to management principles that emphasize the value of environmental sustainability, community and social values that enable the tourists to enjoy their tourism activities and benefit the welfare of local communities. According to Murphy (1988), Larry D, Peter F, Wayne D (2010) in Sunaryo (2013) states that the development of tourism should be a community-based activity, with the main factor that the resources and uniqueness of the local community are either physical elements or non-physical (such as traditions and cultures) inherent in the community must maintain a major movement in tourism. Sunaryo (2013) also added that to make tourism development work well and well managed, the most fundamental thing to do is how to facilitate the wide involvement of local communities in the development process and maximize the value of social and economic benefits of tourism activities for local communities.

\section{Eco Village and Smart Village}

According to Capra in Jafar (2009), ecovillage principles can be applied both to villages or cities for the development and management as well as providing solutions for human or community needs, while at the same time providing environmental protection and improving quality of life for all options. It is based on a deep understanding that living things and everything is interconnected, then ecovillage is a form of human interaction to the environment to achieve sustainable living. According to Nurlaelih in Astrini (2013), ecovillage is 
an environment-based village concept that can overcome urban environmental problems at this time. Subintomo in Astrini (2013) also suggests that ecovillage can be translated as a green village that seeks to create an environmentally friendly settlement area. Green Village implements the preservation of environmental functions in realizing sustainable development, both preserving functions on environmental components (biotic, abiotic and socioeconomic and cultural components and public health). In the development of tourism in the village of ecovillage concept tourism can be built with various facilities such as: Eco-lodge, Eco-recreation, Eco-education, Eco-research, Eco-energy, Eco-development, Eco-promotion.

Smart Village is a development of the notion of smart city which is previously known. According to Nijkamp (2009) in Mujiyono (2016) states smart city is defined as a city capable of using human resources, social capital and modern telecommunications infrastructure to realize sustainable economic growth and high quality of life with wise resource management through government-based public participation. Cohen (2012) in Mujiyono (2016) argues that smart city is a broad approach, integrated in improving the efficiency of the operation of a city, improving the quality of life of its population, and growing its regional economy. According to Muliarto (2015), smart city is how to connect physical infrastructure, social infrastructure and economic infrastructure by using technology, which can integrate all elements in the aspect and make cities more efficient and livable. According to Giffinger (2007) in Mujiyono (2016) considers that the smart city is smart doing the development of the city by looking forward. The approach of urban development that looks forward to the city intelligently considers issues, such as contribution, self-assertiveness, independence, and awareness. According to Giffinger (2007) in Mujiyono (2016), smart city has 6 characteristics, such as: smart economy, smart mobility, smart environmen, smart people, smart living, smart governance.

\section{RESEARCH METHODS}

This research is a descriptive study, with the technique of collecting data of observation, interviews, documentation, focus group discussion with tourism village managers, village heads, hamlet heads in the village of Paksebali and community leaders with 10 sample (purposive sampling). In the FGD questionnaires, it were distributed to identify and provide an assessment (weight and rating) of strengths, weaknesses, opportunities and threats). Filling the questionnaire refers to the following values:

Assessment of current condition: $1=$ very poor; 2 = poor; Angka 3 = fair; 4 = rather good; 5 = good; $6=$ very good

Assessment of the handling urgency: $1=$ not urgent; $2=$ not too urgent; 3 = urgent; 4 = very urgent (Rangkuti $2015: 31$ )

The data obtained were analyzed by descriptive technique. The use of this technique aims to create a description, systematic and objective description, about the facts of the characteristics and the relationship between the elements that exist or a particular phenomenon. Pantiyasa
(2003) suggested that as a form of tourism study, this study was designed to use the interpretive paradigm of social science (Jenings 2001: 38). Furthermore, SWOT analysis (strengths, weaknesses, opportunities, threats) is a systematic identification of various factors to formulate the company's strategy. This analysis is based on logic that can maximize strengths and opportunities, but simultaneously can minimize weaknesses and threats. (Hatch 2015: 19). SWOT Analysis is done by comparing between External factor (EFAS) with Internal factor (IFAS) created on SWOT analysis diagram:

Quadrant 1. It is a very advantegous situation. Companies have the opportunity and power to take advantage of the opportunities that exist. The strategy that must be applied under these conditions is to support an aggressive growth policy

Quadrant 2. Despite facing various threats, the company still has internal strength. The strategy that must be applied is to use the power to take advantage of long-term opportunities with a diversified strategy (product / market)

Quadrant 3. The company faces enormous market opportunities, while on the other hand facing some internal constraints / weaknesses. The company's strategy would focus to minimizes the company's internal problems thus it is seize better market opportunities

Quadrant 4. It is a very unfortunate situation, the company is in the face of various internal threats and weaknesses (Rangkuti 2015 : 21)

\section{RESULTS AND DISCUSSION}

\section{Tourism Potential}

Tourism potential regards to 4A, namely Attraction, Accessibilities, Amenities and Ancillary services.

\section{1) Attraction}

Paksebali village has good tourism potential from its natural potential, its culture as well as handicrafts potential. Therefore, Paksebali Village has been designated as Tourism Village by Klungkung Regent through Klungkung Regent's Regulation no. 2 Year 2017 on Stipulation of Tourism Village. The natural tourist attractions, such as:

a) Kali Unda. It is an unda river which flows that stretched and built a dam to form a giant curtain, in addition, it is the perfect place for selfie and prewedding, besides it is also used for sport tourism, such as rafting. 


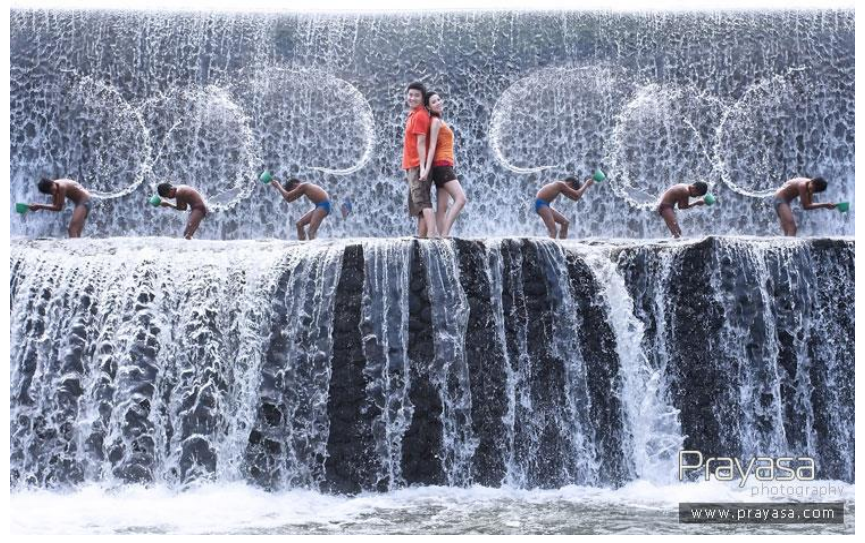

Fig 1. Tukad Unda is a natural tourist attraction as the location of pre-wedding photo as a main product

Source: Village documentation, 2018

b) Paksebali Village Hill. It is a row of hills stretching through Paksebali Village from west to east, these hills are usually used for tracking facilities, selfie and photo group.

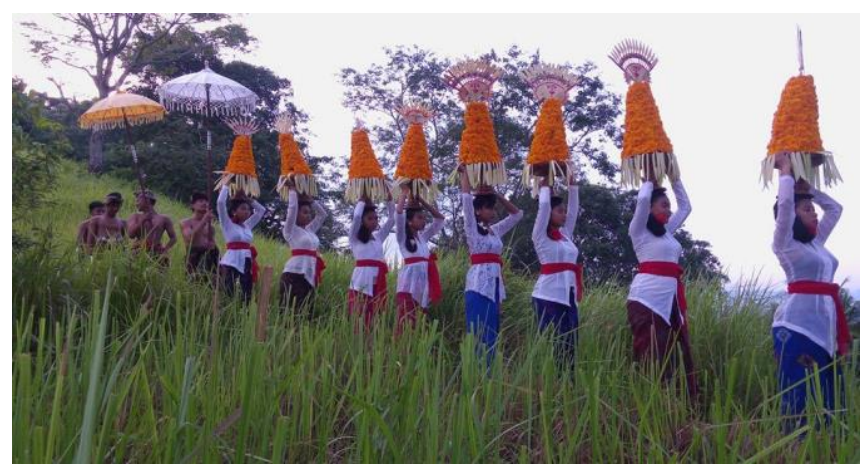

Fig 2. Paksebali Village Hill with beautiful panorama.

Source: Village documentation, 2018

c) Seganing Garden. It is a place of eternal holy water (tirta) by Hindu people or common people used for purifying themselves or as spiritual tourism

Meanwhile, the cultural tourist attraction, such as:

a) Dewa Masraman, this activity is done by the Paksebali Village local once every 6 months precisely on Kuningan day, this culture has been known abroad.

b) Lente Dance. It is a sacred dance that is usually danced at the time of piodalan of Timbrah Panti temple precisely at pahing Piodalan. This dance is performed by local teenage girls. It is a rare dance and only exist in the village of Paksebali

c) Malukat geni or war of fire. This activity is done by the local community of paksebali in Pesamuan or Puri Satria Banjar Kawan which coincides on the feast day before the Nyepi and held once a year

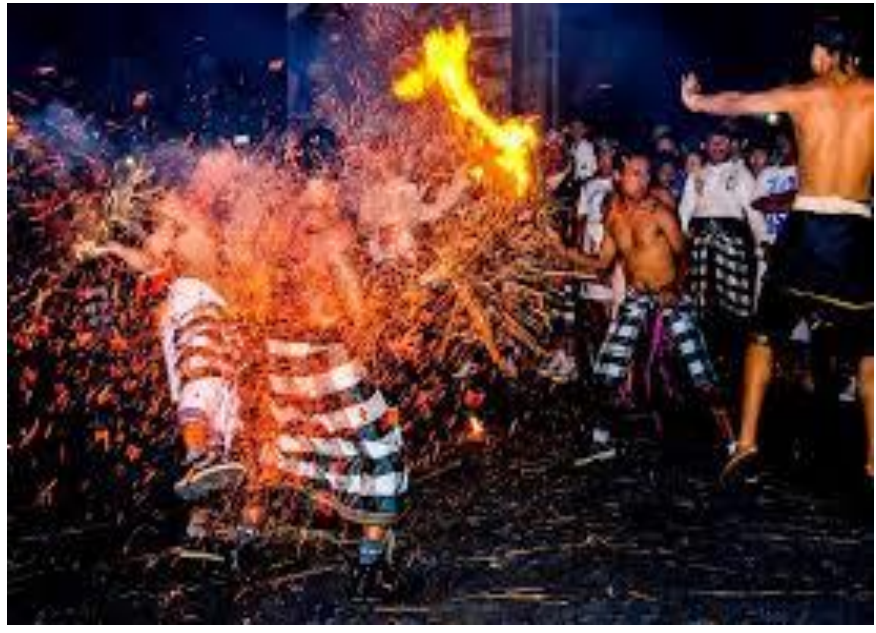

Fig 3. Malukat Geni dance

Source: Village documentation, 2018

d) The performance of Barong Dance, this activity is done if there is a request of visitors or guests who want to see this performance, it is usually held at the time of prawedding activities at Unda River Tourist Attraction.

Furthermore, another Social Community tourist attraction is community-based handicraft. Paksebali Village has a wide range of crafts that are in great demand by local and foreign guests, such as: woven craft of endek, prada, bludru, alang alang roof, gambelan, customized umbrella, reversed glass painting and many more

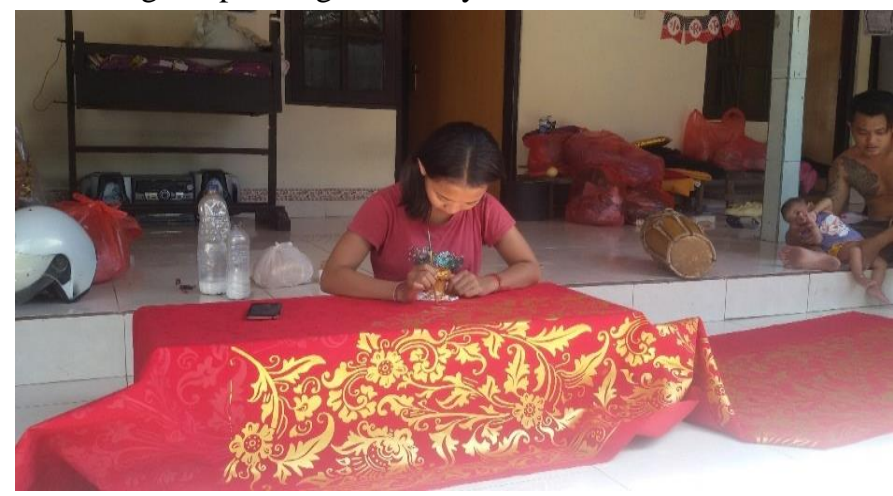

Fig 4. Prada handicraft (painting on the fabric).

Source: Paksebali Village Documentation, 2018

\section{2) Accessibilities}

The access to Paksebali tourism village are as follows:

a) The access to paksebali village is the main road from Semarang city to Karangasem Regency with good condition and supported close to Bay Pass of Prof. Ida Bagus mantra street, so it has easy access from Kuta tourism center, and Nusa Dua

b) Close to the city centre of Semara Pura

c) Located at the touristic route, Kertagosa and Goa lawah as well as close to other tourist destinations such as Pura Besakih. 
3) Amenities

The development of tourist destinations should be supported with facilities to make tourists comfortable and safe to enjoy the tour in the Paksebali Tourism Village. The development and facilities undertaken are:

a) Restaurant. It already has 2 restaurants in which serving food and beverages to the tourists from rafting group with buffet service system and a la carte

b) Tracking Path. The tracking paths are being prepared, and it will be planned to improve more.

c) Public Toilet

d) Parking Area. The Parking area is ample and available, it is especially by utilizing the side of village field and restaurant.

4) Ancillary services. Other supporting services available in the form of providing motorcycle or car rental.

\section{Paksebali Tourism Village Operational Management}

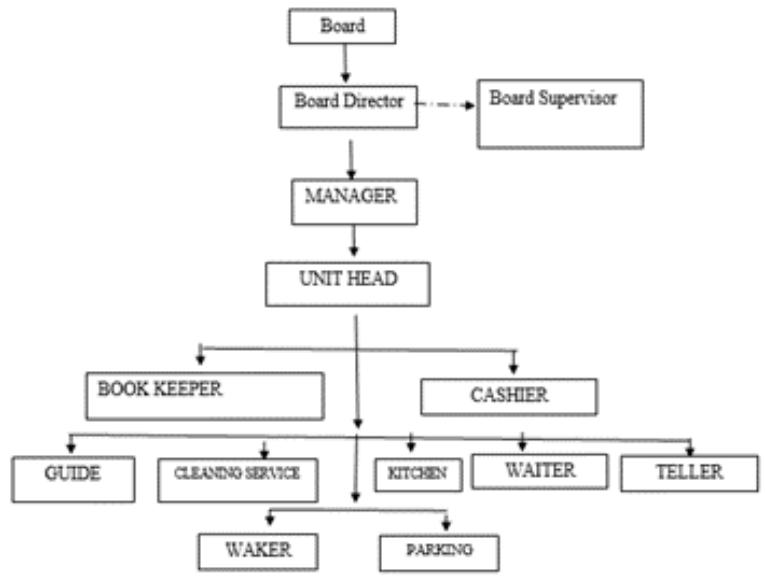

Fig 5. Organizational Structure of Village Business Enterprises (Bumdesa) in Kali Unda Tourist Attraction

Source: Village Business Enterprises of Paksebali Village, 2018

According to the organizational structure, it turns out that the marketing department has not yet been formed, guides have no personnel, some who occupy positions are still double-duty. Officers such as manager, waiter, cashier, teller do not have educational background of hospitality or tourism and have no working experience in their field.

3. The Development Strategy of Paksebali Tourism Village towards smart eco-village destination.

1) The condition of Internal (IFAS) and External (EFAS) Paksebali Tourism village

This is for identifying several internal factors (strength and weakness) and external factors (opportunity and threat)

a) Strengths
- The existence of natural attractions which are not owned by other regions

- Having rare and unique cultural arts

- Having a variety of traditional craft business, which already has a brand image

- Having a location that is purified as a spiritual attraction

- Having a strategic access that is on the famous tourism routes in Bali such as Kertagosa Semara pura, Goa lawah, Candi dasa, Tirta Gangga Karang Asem, close to Ubud, Pura Besakih.

- Facilities for tourism needs are available: restaurants, parking lots, jogging tracks,

- Having a website as a media campaign

- Having tourism village products such as food and beverage sales, rental of pre-wedding photo location, Unda River tourist attraction

- There is a great support from the community

b) Weaknesess

The management of Paksebali tourism village is still very new, it is obvious that there are still some weaknesses, such as:

- Human resource capacity in operational management / management is still not sufficient in terms of educational background and experience

- Not running the business of selling tour packages

- Operational management does not run well where there are still many concurrent positions

- Do not have product marketing personnel

- Lack of business partners in marketing tourism village products

- The tour packages are not ready for sale, because they do not have a tour guide, price list

- Do not have the facilities and infrastructure for selling incoming tickets to the tourist attraction of Unda River

- Do not have an operational information technology (IT) -based system such as financial transactions, ordering systems,

- Do not have security standards for tourists

- There is a habit of the community to do activities, such as bathing, washing, defecating in Unda river, though it is actually the center of tourist attractions.

- $\quad$ Limited fund for tourism village management

c) Opportunities

- The support from the Klungkung Regency government is very good

- There is a regulation that facilitate the development of tourism village

- The interest of tourists to visit ecotourism, increasing both foreign, domestic and local tourists

- Public interest in pre-wedding activities with natural backgrounds is increasing 
- There is an aid from Higher Education, Klungkung regency government and other government agencies.

- Being advance in communication technology

d) Threats

- The occurrence of Mount Agung Eruption, where cold lava flows to the Unda River which will cause silting so that it could interfere with the availability of artificial attractions and also affect the tourists' visit

- The occurrence of environmental pollution of the Unda River due to the effects of community activities such as washing, bathing, also because of the tourists who throw garbage

- Tourist satisfaction demands are increasing

- The occurrence of tourist behavior that is not in accordance with customary norms

2) SWOT Analysis. Based on IFAS and EFAS identification and Focus Group Discussion results

Discussion and assessment of weight and rating of FGD results which are summarized in table 1

Table 1 Recapitulation of weight and rating assessment

\begin{tabular}{|c|c|c|c|c|}
\hline $\begin{array}{l}\text { IFAS (internal Factor } \\
\text { Analysis Strategy) } \\
\text { STRENGTH }(\mathbf{S})\end{array}$ & Woight & Polgtive & Pating & Soono \\
\hline $\begin{array}{l}\text { The existence of natural } \\
\text { attractions which are not } \\
\text { owned by other regions }\end{array}$ & 5.6 & 0.0856 & 3.4 & 0.2911 \\
\hline $\begin{array}{l}\text { Having rare and unique } \\
\text { cultural arts }\end{array}$ & 5.5 & 0.0841 & 3.5 & 0.2943 \\
\hline $\begin{array}{l}\text { Having a variety of } \\
\text { traditional craft } \\
\text { business, which already } \\
\text { has a brand image }\end{array}$ & 5.3 & 0.0810 & 3.6 & 0.2917 \\
\hline $\begin{array}{l}\text { Having a location that is } \\
\text { purified as a spiritual } \\
\text { attraction }\end{array}$ & 4.5 & 0.0688 & 3.4 & 0.2339 \\
\hline $\begin{array}{l}\text { Having a strategic } \\
\text { access that is on the } \\
\text { famous tourism routes } \\
\text { in Bali such as } \\
\text { Kertagosa Semara pura, } \\
\text { Goa lawah, Candi dasa, } \\
\text { Tirta Gangga Karang } \\
\text { Asem, close to Ubud, } \\
\text { Pura Besakih. }\end{array}$ & 4.8 & 0.0734 & 2.4 & 0.1761 \\
\hline $\begin{array}{l}\text { Facilities for tourism } \\
\text { needs are available: } \\
\text { restaurants, parking lots, } \\
\text { jogging tracks, }\end{array}$ & 5.1 & 0.0780 & 3.6 & 0.2807 \\
\hline $\begin{array}{l}\text { Having a website as a } \\
\text { media campaign }\end{array}$ & 4.2 & 0.0642 & 3.7 & 0.2376 \\
\hline $\begin{array}{l}\text { Having tourism village } \\
\text { products such as food } \\
\text { and beverage sales, } \\
\text { rental of pre-wedding } \\
\text { photo location, Unda } \\
\text { River tourist attraction }\end{array}$ & 5.6 & 0.0856 & 3.5 & 0.2997 \\
\hline $\begin{array}{l}\text { There is a great support } \\
\text { from the community }\end{array}$ & 5.5 & 0.0841 & 3 & 0.2523 \\
\hline TOTAL & 46.1 & 0.7049 & & 2.3576 \\
\hline
\end{tabular}

\begin{tabular}{|c|c|c|c|c|}
\hline WEAKNESS $(\mathbf{W})$ & weight & Relative & Rating & Score \\
\hline $\begin{array}{l}\text { Human resource } \\
\text { capacity in operational } \\
\text { management / } \\
\text { management is still not } \\
\text { sufficient in terms of } \\
\text { educational background } \\
\text { and experience }\end{array}$ & 2.2 & 0.0336 & 3.2 & 0.1076 \\
\hline $\begin{array}{l}\text { Not running the } \\
\text { business of selling tour } \\
\text { packages }\end{array}$ & 1.2 & 0.0183 & 3.3 & 0.0606 \\
\hline $\begin{array}{l}\text { Operational } \\
\text { management does not } \\
\text { run well where there are } \\
\text { still many concurrent } \\
\text { positions }\end{array}$ & 3.2 & 0.0489 & 2.2 & 0.1076 \\
\hline $\begin{array}{l}\text { Do not have product } \\
\text { marketing personnel }\end{array}$ & 1 & 0.0153 & 3 & 0.0459 \\
\hline $\begin{array}{l}\text { Lack of business } \\
\text { partners in marketing } \\
\text { tourism village products }\end{array}$ & 2.1 & 0.0321 & 3.6 & 0.1156 \\
\hline $\begin{array}{l}\text { The tour packages are } \\
\text { not ready for sale, } \\
\text { because they do not } \\
\text { have a tour guide, price } \\
\text { list }\end{array}$ & 2 & 0.0306 & 3.8 & 0.1162 \\
\hline $\begin{array}{l}\text { Do not have the } \\
\text { facilities and } \\
\text { infrastructure for selling } \\
\text { incoming tickets to the } \\
\text { tourist attraction of } \\
\text { Unda River }\end{array}$ & 1 & 0.0153 & 3.2 & 0.0489 \\
\hline $\begin{array}{l}\text { Do not have an } \\
\text { operational information } \\
\text { technology (IT) -based } \\
\text { system such as financial } \\
\text { transactions, ordering } \\
\text { systems, }\end{array}$ & 1 & 0.0153 & 2.3 & 0.0352 \\
\hline $\begin{array}{l}\text { Do not have security } \\
\text { standards for tourists }\end{array}$ & 1.2 & 0.0183 & 3.4 & 0.0624 \\
\hline $\begin{array}{l}\text { There is a habit of the } \\
\text { community to do } \\
\text { activities, such as } \\
\text { bathing, washing, } \\
\text { defecating in Unda } \\
\text { river, though it is } \\
\text { actually the center of } \\
\text { tourist attractions. }\end{array}$ & 2.3 & 0.0352 & 3.2 & 0.1125 \\
\hline $\begin{array}{l}\text { Limited fund for } \\
\text { tourism village } \\
\text { management }\end{array}$ & 2.1 & 0.0321 & 2.8 & 0.0899 \\
\hline TOTAL & 19.3 & 0.2951 & & 0.9024 \\
\hline $\begin{array}{l}\text { Overall Total of } \\
\text { Weight x Score (IFAS) }\end{array}$ & 65.4 & 1.0000 & & 3.2601 \\
\hline $\begin{array}{l}\text { EFAS (Eksternal } \\
\text { Factor Analysis } \\
\text { Strategy) }\end{array}$ & & & & \\
\hline (OPPUTUNITY (O) & Weight & Relative & Rating & Score \\
\hline $\begin{array}{l}\text { The support from the } \\
\text { Klungkung Regency } \\
\text { government is very } \\
\text { good }\end{array}$ & 5.8 & 0.1371 & 3.2 & 0.4388 \\
\hline $\begin{array}{l}\text { There is a regulation } \\
\text { that facilitate the } \\
\text { development of tourism } \\
\text { village }\end{array}$ & 4.5 & 0.1064 & 3.1 & 0.3298 \\
\hline $\begin{array}{l}\text { The interest of tourists } \\
\text { to visit ecotourism, } \\
\text { increasing both foreign, } \\
\text { domestic and local } \\
\text { tourists }\end{array}$ & 4.4 & 0.1040 & 3.4 & 0.3537 \\
\hline
\end{tabular}




\begin{tabular}{|l|l|l|l|l|}
\hline $\begin{array}{l}\text { Public interest in pre- } \\
\text { wedding activities with } \\
\text { natural backgrounds is } \\
\text { increasing }\end{array}$ & 5.4 & 0.1277 & 3.5 & 0.4468 \\
\hline $\begin{array}{l}\text { There is an aid from } \\
\text { Higher Education, } \\
\text { Klungkung regency } \\
\text { government and other } \\
\text { government agencies. }\end{array}$ & 5.5 & 0.1300 & 3 & 0.3901 \\
\hline $\begin{array}{l}\text { Being advance in } \\
\text { communication } \\
\text { technology }\end{array}$ & 4.5 & 0.1064 & 3 & 0.3191 \\
\hline TOTAL & $\mathbf{3 0 . 1}$ & $\mathbf{0 . 7 1 1 6}$ & & $\mathbf{2 . 2 7 8 3}$ \\
\hline THREAT (T) & Weight & Relative & Rating & Score \\
\hline $\begin{array}{l}\text { The occurrence of } \\
\text { Mount Agung Eruption, } \\
\text { where cold lava flows to } \\
\text { the Unda River which } \\
\text { will cause silting so that } \\
\text { it could interfere with } \\
\text { the availability of } \\
\text { artificial attractions and } \\
\text { also affect the tourists' } \\
\text { visit }\end{array}$ & 2.2 & 0.0520 & 3.2 & 0.1664 \\
\hline $\begin{array}{l}\text { The occurrence of } \\
\text { environmental pollution } \\
\text { of the Unda River due to } \\
\text { the effects of } \\
\text { community activities } \\
\text { such as washing, } \\
\text { bathing, also because of } \\
\text { the tourists who throw } \\
\text { garbage }\end{array}$ & 3 & 0.0946 & 3.4 & 0.3215 \\
\hline $\begin{array}{l}\text { Tourist satisfaction } \\
\text { demands are increasing }\end{array}$ & 4 & 0.0709 & 3.1 & 0.2199 \\
\hline $\begin{array}{l}\text { The occurrence of } \\
\text { tourist behavior that is } \\
\text { not in accordance with } \\
\text { customary norms }\end{array}$ & 3 & $\mathbf{1}$ & & \\
\hline $\begin{array}{l}\text { TOTAL } \\
\text { Overall Total of } \\
\text { Weight x Score } \\
\text { (EFAS) }\end{array}$ & $\mathbf{4 2 . 3}$ & & & \\
\hline
\end{tabular}

Fig 6. Recapitulation of weight and rating assessment Source: Research data, 2018

\section{Alternative Strategy}

Based on SWOT analysis, an alternative strategy can be formulated in the development of Paksebali tourism village towards smart Eco village destination as follows:

\section{1) Strength Opportunities Strategy (SO)}

It is the strategy to maximize strength indicators to get the following opportunities, such as:

- Gradually manage Unda River so that it becomes more beautiful and attractive,

- Maintaining and preserving inherited cultural art by giving incentives according to financial ability

- Providing guidance to the craftsmen so that their business can be used as a tourist attraction in a sustainable way

- Controlling and maintaining the quality of food and beverages as well as the services
- Maximizing the role of the community in implementing Sapta Pesona and doing marketing through social media

- Expect potential markets, especially the younger generation

2) Strength Threats Strategy (ST)

It is a strategy to use all power to solve problems as the followings:

- Providing socialization to residents or communities about environmental sustainability, hygiene, pollution and behavior and courtesy

- Periodically dredging rivers or in accordance with river silting conditions

- Providing a place for tourists to deliver complaints and suggestions

- Conduct research and evaluation of the quality of food and beverage products and services to tourists

3) Weakness Opportunity Strategy (WO)

It is the strategy which is prepared by controlling the weaknesses of Paksebali tourism villages in order to get opportunities. The strategies are as follows:

- Approaching the government, especially the related ethnic groups to get management guidance, additional capital in managing the tourism village

- Conducting a comparative study to a well-managed the tourism village

- Organizing the organizational structure, especially adding the marketing section

- Recruiting professionals and those whose a commitment to work

- Creating technology information based applications in tourism village marketing

- Collaborating more with travel agents and Rafting companies

- Conducting promotional cooperation with tourism villages in Bali, especially in Indonesia or outside Indonesia

- Conducting training in improving English, cooking, courtesy, tour guides

- Launching tour package products to travel agent companies, schools, government agencies, private and/or public institutions

- Opening opportunities and actively asking for help from universities or academics to carry out community service programs, especially the tourism sector and tourism supporting sectors such as the environment and health

\section{4) Weakness Threat Strategy (WT)}

It is arranged in a way to minimize the weaknesses of Paksebali tourism village in order to avoid the threat as follows:

- Stating written rules, announcements, or things that are prohibited in places that are sanctified by people like a temple and beji

- Stating a rule or ban on garbage disposal in a tourist attraction environment 
- Providing or preparing signs for the safety of tourists

- Complying with safety standards for tourists

- Providing insurance guarantees to tourists The word "data" is plural, not singular.

According to Table 1, it is shown the diagram of SWOT Analysis on Paksebali Village Development to smart Eco village destination, where it is known that the Strengths component score is 2.3576 , the weaknesses component score is 0.9024 , the opportunity component score is 2.2783 threats total component score is 0.9064 , IFAS total score ( total score strengths + weaknesses score number) is $2.3576+0.9024=$ 3.2601, EFAS Total Score (number of opportunities + number of threat scores) is $2.2783+0.9064=.3 .1846$, from these scores, it can be concluded that the coordinate points of $\mathrm{X}$ and $\mathrm{Y}$ axes. The coordinate of the $\mathrm{X}$ axis is by totaling the Strength component score (S) minus the weaknesses component score (W) as follows: $2.3576-0.9024=1.4552$. (positive) The $\mathrm{Y}$ axis axis point is by totalling the opportunities component score (O) minus threats (T) component score as follows: $2.2783-0.9064=1.3719$ (positive). Therefore, the position of Paksebali village is in quadrant I, namely growth oriented strategy. It means that Paksebali Tourism Village is in advantegous position if it could take advantage of opportunities and power to grow and raise. This condition can be described in the Figure 3 below:

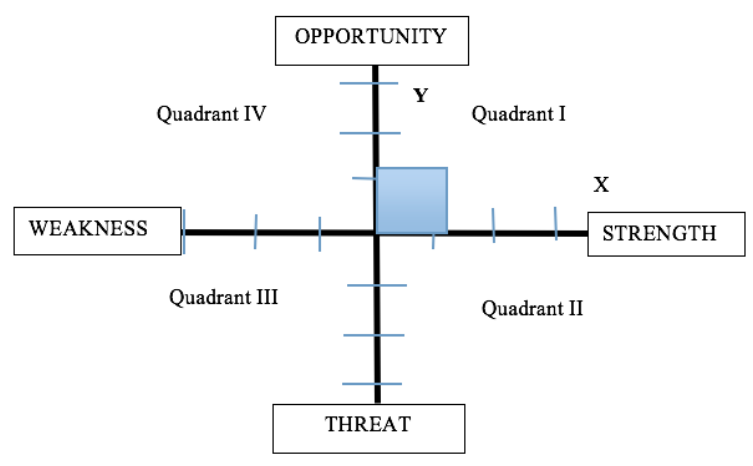

Fig 7. SWOT Analysis of Paksebali Tourism Village Development Source: Research data, 2018

\section{CONCLUSION}

\section{A. Conclusion}

According to the research findings and discussion, it can be concluded as follows:

- There are several enchanting tourist attractions with beautiful nature, unique traditional art and culture, interesting craft and social life that holds the values of tradition and religion, the accessibility is very strategic, it is also supported by the amenities which is continually improved. Thus, Paksebali is very prospective to be developed into a tourism village.

- The organizational structure, duties and functions of each position has been well composed, however it is merely the human resources occupying positions are still incompetent regarding the educational background and experience, also followed by the double position, and the absence of a special section that handles marketing

- In general, several strategies needs to be further implemented in the development of Paksebali tourism village to Smart-Eco Village destination are as follows:

- Natural attractions, especially Unda River, are preserved and not polluted, giving incentives to cultural arts, and developing craftsmen.

- The gradual management and evaluation of Unda River so that it can become a sustainable tourist attraction as well as a new attraction.

- Evaluating the quality of food and beverage products and services in the restaurant

- Reorganizing the operational management or management of tourism villages by adding a special section of marketing and appointing professional marketing officers

- Improving the ability of managers and officers through English language training, tour guide techniques, catering, courtship and successful tourism village comparative studies

- Being more aggressive in promoting especially for IT-based and promoting schools, as well as government and private institutions

- Making a financial management system, IT-based marketing Establish cooperation with Travel agent companies, Tour guides, and increase cooperation with rafting companies

- Conducting socialization to the community about the implementation of Sapta Pesona, as well as delivering the obligations that should not be done in the area of attraction of Unda River.

- Increasing community participation in the supervision and marketing of tourism village products

- Ensuring the safety of tourists through the creation of safety standards, providing safety signs and ensuring tourists who purchase accident-prone tourist products

○ Being Pro-actively asking for help from the government, especially the Klungkung District Government, Higher Education related to improving the competence of human resources, improvement of infrastructure and facilities and management of tourism villages.

\section{B. Suggestion}

According to the conclusions of the research results, it could be suggested several suggestions as follows: 
- The Destination Management Organization should manage Paksebali tourism village by further managing the tourist attraction way better and creating more new tourist attraction in a more creative, especially for the improvement of Unda river

- Paksebali Tourism Village Management should support education towards art and customs by giving reward and incentives

- Planning and building more physical facilities, especially the access to Unda River should be widen, the entrance ticket sales should be made immediately

- Preparing the components of a tour package which will be useful for the tour guide, moreover the price list of tour package should be made, thus it could be published

- Paksebali Tourism Village Manager is more proactive in asking for assistance from related institutions, universities to achieve coaching, training, loan funding

\section{ACKNOWLEDGMENT}

An immense gratitude goes to Ministry of Research, Technology and Higher Education, as the grant for conducting this research. Moreover, this study could also be possible due to the great contribution and cooperation of all stakeholders of Paksebali tourism village for the idea, opinion, suggestion and deep discussion to reveal the best for the improvement of their village. Another gratitude also goes to Sekolah Tinggi Pariwisata Bali Internasional as the Institution who greatly supports the lecturer to conduct research, especially in tourism and hospitality management.

\section{REFERENCES}

[1] Adisasmita, Raharjo. 2006. Membangun DesaPartisipastif Yogyakarta: Graha Ilmu.

[2] Ariadi. 2017. Siap Jadi Desa Wisata Paksebali Buat Jalur "Tracking" di Perbukitan. BaliTravelNews.http://balitravelnews.com/2017/01/26/siap-jadi-desa-wisata-paksebali-buat-jalurtracking-di-perbukitan/. Diakses tanggal 7 Maret 2017.

[3] Ariyanto. 2017. Pemerintah Dukung Pengembangan Desa Wisata Klugkung Bali. Infonawacita.com. https://www.infonawacita.com/pemerintah-dukung-pengembangan desa- wisata-klungkung-bali/. Diakses tanggal 7 Maret 2017.

[4] Astrini, A.P. 2013. Analisis Upaya Masyarakat Dalam Mewujudkan Kampung Hijau, studi kasus Kelurahan Gayamsari, Kota Semarang. Tugas Akhir. Fakultas Teknik Jurusan Perencanaan Wilayah dan Kota, Univeristas Diponogoro.

[5] Cooper, C. et all. 1993. Tourism Principles \& Practice. United Kingdom: Longman Group Limited.

[6] Esram. M. J. 2006. Analisis Pasar Pariwisata dalam Pembangunan Kota Tanjung Pinang Provinsi Kepulauan Riau. Tesis. Semarang: Magister Pembangunan Wilayah dan Kota Undip.
[7] Jenings,gayle. 2001.Tourism research. Austrlia:John Wiley \& Sons Australia Ltd.

[8] Heriyanto. 2014. Persepsi Masyarakat Terhadap Kualitas Pelayanan Publik Pada Bagian Administrasi Kesejahteraan Rakyat Pemerintah Kabupaten Gunungkidul DIY. Skripsi. Jurusan Pendidikan Administrasi, Fakultas Ekonomi, Universitas Negeri Yogyakarta.

[9] Kaelan.2005,Metode penelitian Kualitatif Bidang Filsafat-Paradigma bagi prngembanan Penelitian Interdisipliner Bidang Filsafat,Budaya,,sosial, Semiloka sastra,hukum dan Seni.Yogyakarta :Paradigma.

[10] Kotler, P. dan G. Armstrong. 2001. Prinsip-prinsip Pemasaran, Jilid 1. Edisi Kedelapan. Jakarta: Erlangga.

[11] Madiun, I N. 2008. "Partisipasi Masyarakat Lokal Dalam Pengembangan Kawasan Pariwisata Nusa Dua (Perspektif Kajian Budaya)". Disertasi. Program Studi Doktor Kajian Budaya, Program Pascasarjana Universitas Udayana. Denpasar.

[12] Mujiyono, M dkk. 2016. Kesiapan Kota Pakalongan Menuju Smart City. Jurnal Litbang Kota Pekalongan. 11(1): 107-116.

[13] Nashuilia, AP. 2015. Desa Pintar http://azzradesapintar.blogspot.co.id/. Diakses tanggal 8 Maret 2017.

[14] Pantiyasa I wayan. 2013, Metodologi Penelitian, Yogyakarta, Andi offset

[15] Priasukmana, S \& R.M. Mulyadi. 2001. Pembangunan Desa Wisata: Pelaksanaan Undang-Undang Otonomi Daerah. Info Sosial Ekonomi. 2 (1): 37-44.

[16] Rahayu, W.P. dkk. 2003. Klasifikasi Bahan Pangan dan Resiko Keamanannya. Jakarta: PT. Gramedia Pustaka Utama.

[17] Rakhmat, J. 2007. Persepsi Dalam Proses Belajar Mengajar. Jakarta: Rajawali Pers.

[18] Rangkuti, F. 2006. Measuring Customer Satisfaction. Jakarta: PT. Gramedia Pustaka Utama.

[19] ---------, 2015. Tehnik Membedah Kasus Bisnis Analisis SWOT, Jakarta: PT. Gramedia Pustaka Utama.

[20] Rencana Strategis Dinas Pariwisata Kabupaten Klungkung 2013-2018

[21] Shodiq, J. 2009. Perencanaan Kampung Berbasis Lingkungan (Ecovillage) di Kawasan Penyangga Taman Nasional Ujung Kulon Banten. Skripsi. Program Studi Arsitektur Lanskap, Fakultas Pertanian, Institut Pertanian Bogor.

[22] Sudria munawar, Haryono. 2006. Kepemimpinan, Peran Serta, Produktivitas. Bandung: Mandar Maju.

[23] Sunaryo, B. 2013. Kebijakan Pembangunan Destinasi Pariwisata Konsep dan Aplikasinya Indonesia. Yogyakarta: Gava Media.

[24] Tunjungsari, K.R. 2016. Persepsi Masyarakat Kuta Terhadap Dampak Pembangunan Hotel Berkonsep City Hotel di Sunset Road Kuta Bali. Proposal Penelitian. Dikti.

[25] Undang-undang Republik Indonesia No 10 tahun 2009 tentang Kepariwisataan

[26] Undang-undang Republik Indonesia No 10 tahun 2009 tentang Kepariwisataan

[27] Yoeti, O.A. 2002. Perencanaan dan Pengembangan Pariwisata. Jakarta: PT Pradaya Paramita.

[28] Yustina, K. 2015. Promosi Pariwisata di Media Online Dianggap 4 Kali Lebih Efektif. TravelNews. Com. 